\title{
Effect of Bali Cattle Ovarian Status on Oocytes Nuclear Maturation and In Vitro Fertilization Rate
}

\author{
Sonjaya $\mathrm{H}^{1}$, Yusuf $\mathrm{M}^{1}$, Hamdana $\mathrm{A}^{1}$, Utamy $\mathrm{RF}^{1}$, Gustina $\mathrm{S}^{2}$, Hasbi $\mathrm{H}^{1}$ \\ ${ }^{I}$ Department of Livestock Production, Faculty of Animal Science, University of Hasanuddin, \\ Jl. Perintis Kemerdekaan Km.10, Makassar 90245, Indonesia \\ ${ }^{2}$ Department of Animal Science, Faculty of Animal and Fisheries Science, University of West Sulawesi, \\ Jl. Prof. Dr. Baharuddin Lopa, Tande Timur, Majene, 91412 \\ E-mail: hasbi_fapetunhas@yahoo.com
}

(received 09-10- 2017; revised 13-11-2017; accepted 02-12-2017)

\begin{abstract}
ABSTRAK
Sonjaya H, Yusuf M, Hamdana A, Utamy RF, Gustina S, Hasbi H. 2017. Pengaruh status ovarium sapi Bali terhadap maturasi inti oosit dan tingkat fertilitas in vitro. JITV 22(4): 173-178. DOI: http://dx.doi.org/10.14334/jitv.v22i4.1585

Penelitian ini dilakukan untuk mengetahui pengaruh status reproduksi ovarium yang ditandai dengan keberadaan corpus luteum (CL) dan folikel dominan (FD) terhadap tingkat pematangan inti dan fertilisasi oosit sapi bali in vitro. Pasangan ovarium dari rumah potong hewan (RPH) dipisahkan menjadi empat kelompok, yaitu: 1) ovarium dengan CL dan FD, 2) ovarium tanpa CL dan ada FD, 3) ovarium dengan CL dan tanpa CL, dan 4) ovarium tanpa CL dan FD. Penelitian ini dibagi dalam dua tahap. Tahap I, oosit dikoleksi dengan teknik pencacahan dalam medium Phosphate Buffer Saline (PBS) yang disuplementasi dengan Fetal Bovine Serum (FBS) $10 \%$ dan penicilin streptomycin $100 \mathrm{IU} / \mathrm{ml}$. Oosit dimatangkan selama 24 jam, $38,5^{\circ} \mathrm{C}$ dalam inkubator CO2 5\%, menggunakan medium TCM-199 yang disuplementasi dengan FBS 10\%, Follicle Stimulating Hormone (FSH) $10 \mathrm{IU} / \mathrm{ml}$, Luteinizing Hormone (LH) $10 \mathrm{IU} / \mathrm{ml}$, dan gentamycin $50 \mu \mathrm{g} / \mathrm{ml}$. Tahap II, oosit dimatangan dalam media seperti pada penelitian tahap I, kemudian difertilisasi secara in vitro untuk mengamati pembentukan pronukleus. Hasil penelitian tahap I menunjukkan bahwa jumlah oosit yang mencapai fase metaphase II (MII) lebih tinggi $(\mathrm{P}<0,01)$ pada pasangan ovarium ada CL dan tanpa FD $(89,47 \%)$ dibandingkan dengan tanpa CL dan tanpa FD $(75,47 \%)$, tanpa CL dan ada FD $(74,41 \%)$, dan ada CL dan ada FD $(65,52 \%)$. Status reproduksi ovarium yang memiliki CL tetapi tanpa FD memiliki jumlah oosit yang mencapai tahap MII tertinggi. Penelitian tahap II menunjukkan bahwa status reproduksi ovarium tidak berpengaruh terhadap tingkat fertilisasi oosit sapi bali. Hasil penelitian menyimpulkan bahwa persentase oosit yang mencapai tahap MII dari ovarium yang memiliki CL dan tidak memiliki FD tertinggi, namun tingkat fertilisasi tidak dipengaruhi oleh status reproduksi ovarium.
\end{abstract}

Kata Kunci: Status Ovarium, Oosit, Sapi Bali, Pematangan, Fertilisasi

ABSTRACT

Sonjaya H, Yusuf M, Hamdana A, Utamy RF, Gustina S, Hasbi H. 2017. Effect of Bali cattle ovarian status on oocytes nuclear maturation and in vitro fertilization rate. JITV 22(4): 173-178. DOI: http://dx.doi.org/10.14334/jitv.v22i4.1585

The aim of this study was to investigate whether the reproductive status influences the nuclear maturation and fertilization rates of bali cattle oocytes in vitro. Several pairs of ovary were classified into four groups: 1) ovaries with Corpus Luteum (CL) and Dominant Follicle (DF), 2) ovaries without CL and with DF, 3) ovaries with CL and without DF, 4) ovaries without both CL and DF. In the first experiment, oocytes were collected by slicing method in Phosphate Buffer Saline (PBS) medium supplemented with $10 \%$ Fetal Bovine Serum (FBS) and $100 \mathrm{IU} / \mathrm{ml}$ penicillin streptomycin. Oocytes were matured in tissue culture medium (TCM)-199 supplemented with 10\% Fetal Bovine Serum (FBS), 10 IU/ml Follicle Stimulating Hormone (FSH), $10 \mathrm{IU} / \mathrm{ml}$ Luteinizing Hormone (LH), and $50 \mu \mathrm{g} / \mathrm{ml}$ gentamycin. Oocytes were matured in $5 \% \mathrm{CO} 2$ incubator, $38^{\circ} \mathrm{C}$ for $24 \mathrm{~h}$. In the second experiment, oocytes were matured and then fertilized in vitro to observe pronuclear formation. The first experiment showed that the percentage of oocytes reached methaphase-II (MII) stage on ovaries with CL and without DF (89.47\%) were higher $(\mathrm{P}<0,01)$ compared to ovaries without both CL and DF $(75,47 \%)$, ovaries without CL and with DF $(74 ., 41 \%)$, or ovaries with CL and DF $(65,52 \%)$. The result of second experiment showed that the ovarian reproductive status was not significantly different $(\mathrm{P}>0.05)$ on fertilization rate.

Key Words: Ovarian Status, Oocytes, Bali Cattle, Maturation, Fertilization

\section{INTRODUCTION}

Embryo production in vitro (EPIV) is one of the assisted reproductive technology (ART) consisted of in vitro maturation (IVM), in vitro fertilization (IVF) and in vitro culture (IVC) (Rahman et al. 2008, Hegab et al. 2009). Genetic material of the animal with abnormal reproduction function may be rescued by this EPIV technology. 
The success of the EPIV technology is determined by many factors, such as oocytes source used. Oocytes grow in the follicle environment in the ovary following certain growth circle. Follicle growth wave consists of recruitment phase, selection, dominant and some have atresia (Campanile et al. 2010). In cattle and sheep, it is possible for several follicle waves in one estrus circle, generally two to three times in sheep which each may produce more than dominant follicle (DF) (Evans 2003). This dominant follicle existence will decrease FSH concentration (Gonzalez-Bulnes et al. 2004) and leading a pressure to other follicle growths in the same wave causing a regression (Varishaga et al. 1998). Then, the DF will ovulate if there is no corpus lutheum (CL). Remnant of ovulated DF forms CL. This CL consists of cells that will produce progesterone hormone useful in implantation process and pregnancy maintenance. The aim of this study was to investigate whether the reproductive status influences the nuclear maturation and fertilization rates of bali cattle oocytes in vitro.

\section{MATERIALS AND METHODS}

\section{Stage I. Oocytes collection and maturation In Vitro}

Ovarium of bali cattle were collected from a slaughterhouse and transported to the laboratory in the solution of $0.9 \% \mathrm{NaCl}$ supplemented with $100 \mathrm{IU} / \mathrm{ml}$ penicilin and $100 \mu \mathrm{g} / \mathrm{ml}$ streptomycin sulfate. Oocyte collection was performed by aspiration technique using a 18-G syringe. Phosphate buffered saline (PBS) supplemented with $10 \%$ fetal bovine serum (FBS) (Sigma, USA) was used as the collection medium. Oocytes with homogenous cytoplasm and surrounded by $\geq 3$ layers of cumulus cells were selected under a stereo-microscope and were graded into either A or B (Abdoon et al. 2014). The selected oocytes were washed three times in the maturation media, then the maturation was performed in the tissue culture medium (TCM) 199 (Sigma, USA) supplemented with $10 \mathrm{IU} / \mathrm{ml}$ pregnant mare serum gonadotrophin (PMSG) (Intergonan, Intervet Deutschland $\mathrm{GmbH}$ ), $10 \mathrm{IU} / \mathrm{ml}$ human chorionic gonadotrophin (hCG) (Chorulon, Intervet international B.V. Boxmeer-Holland), $1 \mu \mathrm{g} / \mathrm{ml}$ estradiol (Intervet international B.V. Boxmeer-Holland) and $50 \mu \mathrm{g} / \mathrm{ml}$ gentamycin (Sigma, USA). The oocyte maturation was performed in a 35-mm Petri dish (Nunclon, Denmark) in the form of drop, $50 \mu \mathrm{l}$ in volume, containing 10-15 oocytes per drop, covered with mineral oil (Sigma, USA). The oocytes were incubated in a $5 \% \mathrm{CO}_{2}, 38.5^{\circ} \mathrm{C}$ incubator for 24 hours (modified from Hasbi et al. 2017).

\section{Evaluation of nucleus maturation level and the staining process}

Evaluation of nucleus maturation level was assessed on the basis of meiosis from germinal vesicle $(\mathrm{GV})$ to metaphase II (MII) on 2\%-aceto-orcein staining. Germinal vesicle stage was characterised by a clearly visible nucleus and its membrane. Germinal vesicle breakdown (GVBD) was marked by the fragmentation of the nucleus membrane and indistict nucleus. Metaphase I (MI) was marked by the existence of homolog chromosomes lined up in the equator, whereas in the anaphase I (AI) stage, the chromosomes were moved to both poles. In the telophase I (TI) stage, the chromosomes had reached both poles. Metaphase II (MII) was marked by polar body I and the same chromosome structure with the one in the MI stage (Shirazi \& Sadeghi 2007). Nucleus maturation level was determined on the basis of oocytes percentage able to reach the MII (Bijttebier et al. 2008).

After 24 hours maturation, the cumulus cells surrounding the oocytes were removed using $0.25 \%$ hyaluronidase (Sigma, USA) followed by denotation by repeated pipetting using a 110-120 $\mu \mathrm{m}$ syringe (according to oocyte size). The oocytes were suspended in $0.7 \% \mathrm{KCl}$ and placed as a drop on the cover glass with paraffin and vaseline pads in its four corners. The cover glass was placed upside down on an object glass. The oocytes were fixed by dipping the glasses into fixation solution consisting of acetic acid and ethanol (1 : 3 ) for 3 days. The cells were dehydrated by soaking in ethanol, then stained with $2 \%$ aceto-prcein for 5 minutes. The dye was cleaned using $25 \%$ acetate acid and the four corners of cover glass was smeared by clear nail polish. Then, the morphology of the oocytes was performed under microscope (Zeiss Axio Imager A2) using Zeiss Axiocam HRc.

\section{Stage II. In Vitro fertilization}

Collection and maturation of oocytes followed the same procedure as in the stage I. Frozen semen was thawed in $37^{\circ} \mathrm{C}$ for 20 second and then centrifuged at $700 \mathrm{G}$ for 5 minutes in the fertilization media (Suzuki et al. 2000). After the centrifugation, sperm sediment was suspended in fertilization media to a concentration of $1.5 \times 10^{6}$ spermatozoa $/ \mathrm{ml}$. After the IVM, the oocytes were washed in fertilization media twice, then moved into drop fertilization media (10-15 oocytes in $100 \mu \mathrm{l}$ fertilization media) and covered with mineral oil (Sigma-Aldrich. Inc, M-8410) followed by incubation at $38.5^{\circ} \mathrm{C}$ for 16 hours in $5 \% \mathrm{CO}_{2}$ incubator (modified from Hasbi et al. 2017). Fertilization level was evaluated in a basis of pronucleus formation with $2 \%$ aceto-orcein staining as in stage 1. 


\section{Data analysis}

Data were presented in the form of percentage. Differences between treatments were analyzed using ANOVA. In case significant differences were found, the smallest real test was carried out. All statistical analyses were carried out using SPSS 17 (SPSS $\left.{ }^{\text {Inc }}\right)$.

\section{RESULTS AND DISCUSSION}

\section{Maturation stage of oocytes nucleus}

Oocyte in vitro maturation stage is detemined by quality of the oocytes used. In this study, cumulus cells were formed after in vitro maturation for 24 hours (Figure 1B). Rahman et al. (2008) reported that formation of cumulus cells is followed by changes in the gap junction consisted of transmembrane channels. The latter were formed by hexamer proteins including connective proteins. In horse, cattle, sheep and mouse, the cumulus cells have about 43 connective proteins. The existence of cumulus cells played a crucial role in the protein synthesis process before the germinal vesicle breakdown (GVBD). In sheep and cattle oocytes, the GVBD functions as supply of nutrient, energy substrate, messenger molecules for oocytes development and hormone effect in the cumulus oocyte complexes (COCs) (Rahman et al. 2008).

The communication between oocytes and cumulus cells plays crucial role in future maturation and development process of oocytes during IVC. Tthe communication is connected by gap junctional communication (GJC), where the components activate the meiosis process, glutathione or substrate glutamine and cysteine, a small regulator molecule lighter than 1 $\mathrm{kDa}$, substrat molecule with lighter than 1,200 Da such as $\mathrm{Ca}^{2+}$; nucleotide and amino acids are transferred from cumulus cells through the GJC (Shirazi et al. 2007).

This study showed that the most matured oocytes have started the meiosis stage indicated by the change of nuclear oocytes from GV to MII stages (Figure 1CF). The number of oocytes reached MII stage based on the ovarium reproduction status was presented in the Table 1.

This study showed that reproduction status of ovary was significantly $(\mathrm{P}<0.01)$ influenced the number of oocyte of bali cattle that reached metaphase II (MII) stage. The statistic test showed reproduction status of ovary +CL $-\mathrm{FD}(89.47 \%)$ had more $(\mathrm{P}<0.01)$ oocytes reached MII than the +CL +FD (65.52\%), -CL +FD $(74.41 \%)$, and -CL -FD $(75.47 \%)$. Whereas, the number of oocytes reached MII stage in the ovary -CL $+\mathrm{FD}$ was not different $(\mathrm{P}>0.05)$ with the ovary $-\mathrm{CL}$ -
FD, but significantly higher than the $+\mathrm{CL}+\mathrm{FD}$. The existence of CL and DF on the ovarian couple affects in vitro maturation stage of oocyte nucleus of bali cattle.

Generally, maturation stage of oocytes nucleus from ovarian couple that have CL and DF tends to be lower. This showed that progesterone from the CL and inhibin from the DF gives a negative effect to in vitro maturation process of nucleus. Ooe et al. (1997) reported that in the cattle, ultrasonography use and FSH hormone administration showed that the number of follicle, the number of aspirated oocyte, the number of life oocyte which then experiencing division and forming blastocyst in vitro; the lowest was in the animal with DF compared to the animal without DF. This FSH administration on the animal with DF did not give positive response to subordinate follicle development. In vice versa, Boediono \& Setiadi (2006) stated that CL existence in the ovary has positive correlation with the number of grow follicle. Progesterone produced from CL may inhibit DF growth and remove inhibin effect, so that subordinate follicle is able to grow (Kor 2014). Varishaga et al. (1998) reported that the highest number of collected oocyte, division and blastocyst level was obtained from the ovary with $\mathrm{CL}$ and without DF followed by oocyte from ovary with CL and DF. Then, Vassena et al. (2003) reported that there was no significant difference in blastocyst level result of cattle in basis of the difference of reproduction status of ovary marked by CL and DF existence. Even though, generally the blastocyst level continue to rise on the ovary with CL. This is allegedly that CL produced progesterone plays a role to conquer negative effect inflicted by inhibin existence. High $\mathrm{A}$ inhibin on the follicle will drive to FSH secretion and another follicles development on the cattle, sheep and buffalo (Perera 2011)

\section{In Vitro fertilization level of oocytes}

Fertilization level was assessed by counting the number of oocyte forming two or more pronucleus (Figure 2).

This study showed that reproduction status of ovary did not significantly affect $(\mathrm{P}>0.05)$ the number of fertilized oocytes (forming two or more pronucleus). This study also revealed a higher fertility level $(60.29 \%)$ on the oocyte from ovary without CL and DF than other ovary reproductive status (Table 2). The quality of oocyte used in this study was uniform with the homogenous cytoplasm surrounded by compact cumulus cells indicating a uniform development. This study also provided an indication that inhibit supposedly produced by DF may not affect in vitro fertility level of bali cattle oocytes. 

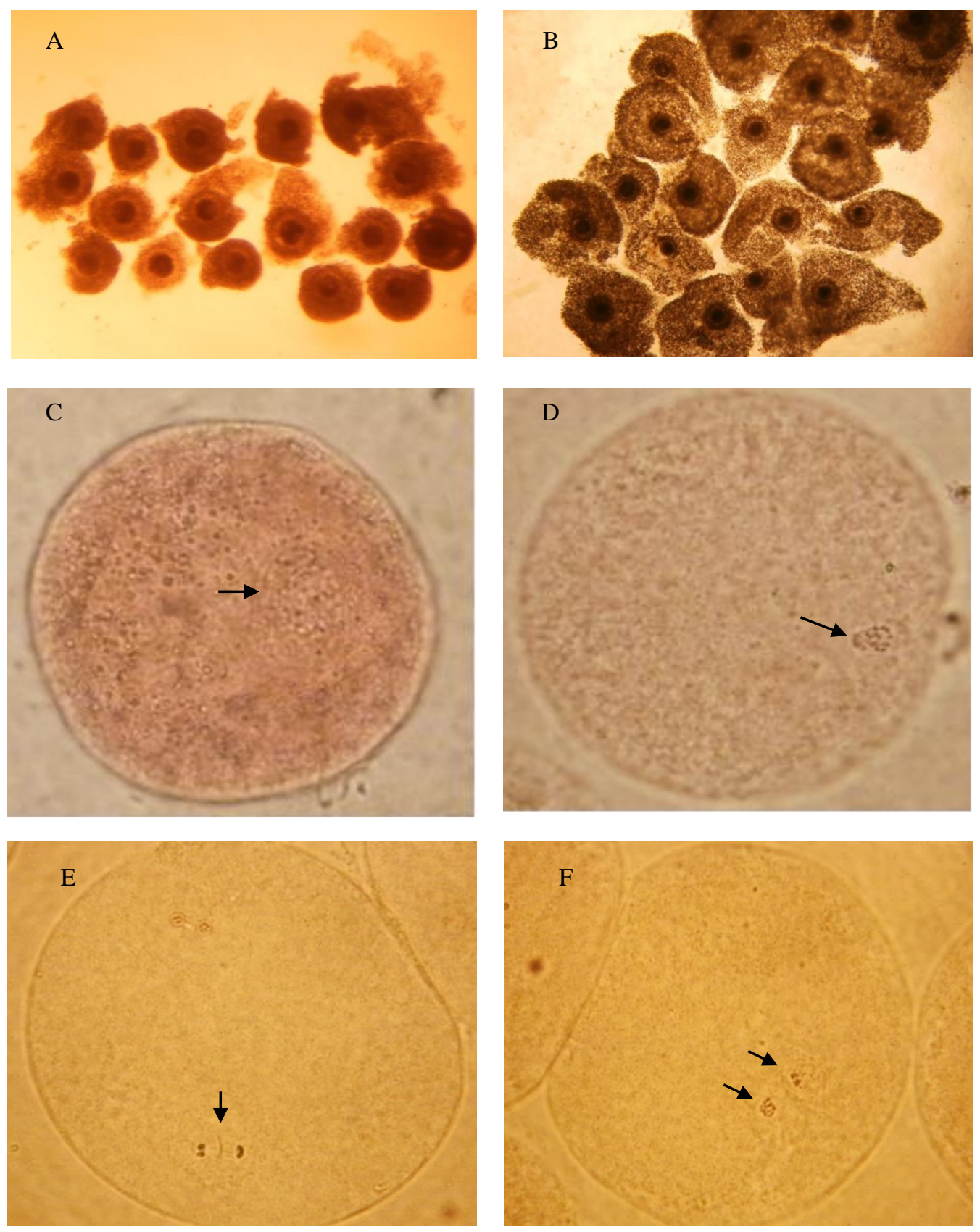

Figure 1. The development of bali-cattle oocyte. A. Oocyte before maturation ( $200 \mathrm{x}$ magnification), B. Oocyte after maturation (200 x magnification), O: Oocyte (SK: cumulus cells, and ESK: cumulus cell expansion), C. Germinal Vesicle (GV), D. Metaphase I (MI), E. Anaphase/Telophase (A/T), and F. Metaphase II (MII) (the arrows).

The success of in vitro fertilization is highly influenced by oocyte source used. The criterion of oocytes used in this study was homogenous cytoplasm surrounded by compact cumulus cells. Those oocytes were expected from tertiary follicle that have the ability to start the meiosis process. Oocytes from tertiary follicle is reported to produce reactive oxygen species
(ROS) component, antioxidant, hormone, metabolite (Hennet \& Combelles 2012), glucose, pyruvate, and glycine (Pinero-Sagredo et al. 2010) playing crucial roles to promote fertility process.

The meiosis process is started by activating $\mathrm{G}$ protein that activated phospholipase $\mathrm{C}$, which in turn hydrolyzed phosphoinositide to form inositol 
Table 1. Maturation stage of cattle oocyte nucleus from ovary with different reproduction status

\begin{tabular}{|c|c|c|c|c|c|c|c|}
\hline \multirow{2}{*}{\multicolumn{2}{|c|}{$\begin{array}{l}\text { Reproduction } \\
\text { Status of Ovary }\end{array}$}} & \multirow{3}{*}{$\begin{array}{c}\text { The number of } \\
\text { oocytes }\end{array}$} & \multicolumn{5}{|c|}{ Maturation Stage of Nucleus (\%) } \\
\hline & & & \multirow{2}{*}{$\frac{\mathrm{GV}}{1(1.72)}$} & \multirow{2}{*}{$\frac{\text { GVBD }}{0(0.00)}$} & \multirow{2}{*}{$\frac{\text { MI }}{19(32.76)}$} & \multirow{2}{*}{$\begin{array}{c}\mathrm{AI} / \mathrm{TI} \\
0(0.00)\end{array}$} & \multirow{2}{*}{$\frac{\text { MII }}{38(65.52)^{\mathrm{a}}}$} \\
\hline$+\mathrm{CL}$ & $+\mathrm{FD}$ & & & & & & \\
\hline$-\mathrm{CL}$ & $+\mathrm{FD}$ & 43 & $1(2.33)$ & $0(0.00)$ & $9(20.93)$ & $1(2.33)$ & $32(74.41)^{\mathrm{b}}$ \\
\hline$+\mathrm{CL}$ & $-F D$ & 57 & $0(0.00)$ & $0(0.00)$ & $6(10.53)$ & $0(0.00)$ & $51(89.47)^{\mathrm{c}}$ \\
\hline$-\mathrm{CL}$ & -FD & 53 & $0(0.00)$ & $0(0.00)$ & $13(24.53)$ & $0(0.00)$ & $40(75.47)^{\mathrm{b}}$ \\
\hline
\end{tabular}

Description: +CL: CL present, -CL: CL absent CL, +FD DF present:, -FD: DF absent, GV: germinal vesicle, GVBD: germinal vesicle breakdown, MI: metaphase I, AI-TI: anaphase I/telophase I, MII: metaphase II. Different superscript in the same column means significant different $(\mathrm{P}<0.01)$
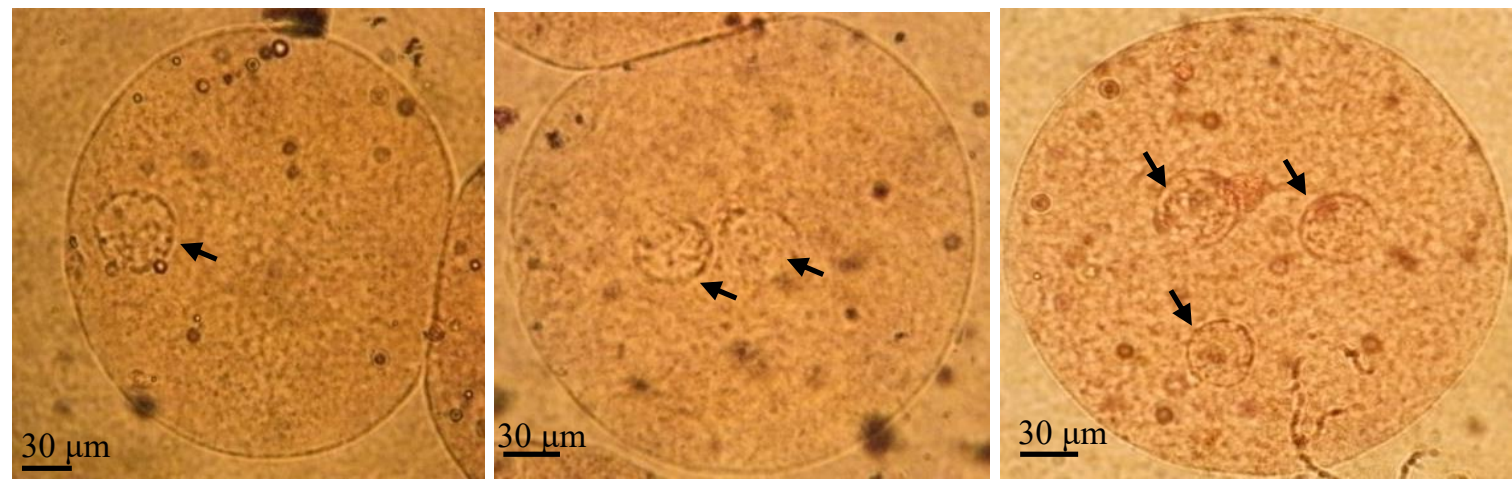

Figure 2. Forming of pronucleus after in vitro fertilization process: A. one pronucleus, B. two pronucleuses, C. three pronucleuses (the arrow).

Table 2. Fertilization level of bali cattle oocytes from ovarium with different reproduction status

\begin{tabular}{|c|c|c|c|c|c|c|}
\hline \multirow{2}{*}{$\begin{array}{l}\text { Reproduction } \\
\text { status of ovary }\end{array}$} & \multirow{2}{*}{$\begin{array}{l}\text { The number } \\
\text { of oocyte }\end{array}$} & \multicolumn{4}{|c|}{ Forming of pronucleus } & \multirow{2}{*}{ Fertilization level (\%) } \\
\hline & & $0 \mathrm{PN}(\%)$ & $1 \mathrm{PN}(\%)$ & $2 \mathrm{PN}(\%)$ & >2 PN (\%) & \\
\hline$+\mathrm{CL}+\mathrm{FD}$ & 47 & $3(6.38)$ & $17(36.17)$ & $14(29.79)$ & $13(27.66)$ & $27(57.44)$ \\
\hline$-\mathrm{CL}+\mathrm{FD}$ & 41 & $9(21.95)$ & $11(26.83)$ & $12(29.27)$ & $9(21.95)$ & $21(51.21)$ \\
\hline$+\mathrm{CL}-\mathrm{FD}$ & 58 & $22(37.93)$ & $17(29.31)$ & $10(17.24)$ & $9(15.52)$ & $19(32.76)$ \\
\hline$-\mathrm{CL}-\mathrm{FD}$ & 68 & $2(2.94)$ & $25(36.76)$ & $22(32.35)$ & $19(27.94)$ & $41(60.29)$ \\
\hline
\end{tabular}

Description: PN: Pronucleus.

triphosphate mobilizing intracellular $\mathrm{Ca}^{2+}$ followed by influx of extracellular $\mathrm{Ca}^{2+}$ (Ajduk et al. 2008). Influx extracellular $\mathrm{Ca}^{2+}$ may inhibit adenylyl cyclase leading to decrease of cAMP/PKA and also may activate calmoduline-dependent protein kinase (CaM II kinase) which will modify or activate the maturation promoting factor (MPF) (Oh et al. 2010; Conti et al. 2012). Brevini et al. (2007) reported that distribution of organelle on the cytoplasm is closely related to the oocyte maturation and competition. Consequently, maturation of imperfect cytoplasm from the oocyte reached MII stage was allegedly to lead to low success of in vitro embryo production (Blanco et al. 2011).

\section{CONCLUSION}

The number of oocytes from ovarium of bali cattle with corpus luteum (+CL) and and without dominant follicle (-FD) reached metaphase-II stage (MII) was higher compared to the oocytes from other ovarium $(+\mathrm{CL},+\mathrm{FD} ;-\mathrm{CL},+\mathrm{FD}$ or $-\mathrm{CD},-\mathrm{CD})$. However, reproduction status of ovarium did not affect the fertility level. 


\section{REFERENCES}

Abdoon AS, Gabler C, Holder C, Kandil OM, Einspanier R. 2014. Seasonal variations in developmental competence and relative abundance of gene transcripts in buffalo (Bubalus bubalis) oocytes. Theriogenology 82:10551067.

Ajduk A, Małagocki A, Maleszewski M. 2008. Cytoplasmic maturation of mammalian oocytes: development of a mechanism responsible for sperm-induced $\mathrm{Ca} 2+$ oscillations. Reprod Biol. 8:3-22.

Bijttebier J, Van Soom A, Meyer E, Mateusen B, Maes D. 2008. Preovulatory follicular fluid during in vitro maturation decreases polyspermic fertilization of cumulus-intact porcine oocytes in vitro maturation of porcine oocytes. Theriogenology. 70:715-724.

Blanco MR, Demyda S, Moreno-Millán M, Genero E. 2011. Developmental competence of in vivo and in vitro matured oocytes: A review. Biotechnol Mol Biol Rev. 6:155-165.

Boediono A, Setiadi MA. 2006. Tingkat pematangan inti oosit domba dari ovarium dengan status reproduksi dan medium maturasi yang berbeda. Hayati J Biosci. 13:131-136.

Brevini TL, Cillo F, Antonini A, Gandolfi F. 2007. Cytoplasmic remodeling and the acquisition of developmental competence in pig oocytes. Anim Reprod Sci. 98:23-38.

Campanile G, Baruselli PS, Neglia G, Vecchio D, Gasparrini B, Gimenes LU, Zicarelli L, D’Occhio MJ. 2010. Ovarian function in the buffalo and implications for embryo development and assisted reproduction. Anim Reprod Sci. 121:1-11.

Conti M, Hsieh M, Zamah AM, Oh JS. 2012. Novel signaling mechanisms in the ovary during oocyte maturation and ovulation. Mol Cell Endocrinol. 356:65-73.

Evans ACO. 2003. Ovarian follicle growth and consequences for fertility in sheep. Anim Reprod Sci. 78:289-306.

Gonzalez-Bulnes A, Souza CJH, Campbell BK, Baird DT. 2004. Systemic and intraovarian effects of dominant follicles on ovine follicular growth. Anim Reprod Sci. 84:107-119.

Hasbi H, Gustina S, Karja NWK, Supriatna I, Setiadi MA. 2017. Insulin-like growth factor-I concentration in the follicular fluid of bali cattle and its role in the oocyte nuclear maturation and fertilization rate. Media Peternakan. 40:7-13.
Hegab AO, Montasser AE, Hamman AM, Abu El-Naga EMA, Zaabel SM. 2009. Improving in vitro maturation and cleavage rates of buffalo oocytes. Anim Reprod. 6:416-421.

Hennet ML, Combelles CMH. 2012. The antral follicle: a microenvironment for oocyte differentiation. Int $\mathrm{J}$ Dev Biol. 56:819-831

Kor NM. 2014. The effect of corpus luteum on hormonal composition of follicular fluid from different sized follicles and their relationship to serum concentration in diary cows. Asian Pac J Trop Med. 7:S282-S288.

Oh JS, Han SJ, Conti M. 2010. Wee1B, Myt1, and Cdc25 function in distinct compartments of the mouse oocyte to control meiotic resumption. J Cell Biol. 188:199-207.

Ooe M, Rajamahendran R, Boediono A, Suzuki T. 1997. Ultrasound-guided follicle aspiration and IVF in dairy cows treated with FSH after removal of estrous cycle. J Vet Med Sci. 59:371-376.

Perera BM. 2011. Reproductive cycles of buffalo. Anim Reprod Sci. 124:194-199.

Pinero-Sagredo E, Nunes S, Delossantos MJ, Celda B, Esteve V. 2010. NMR metabolic profile of human follicular fluid. NMR Biomedicine. 23:485-495.

Rahman ANMA, Abdullah RB, Wan Khadijah WE. 2008. In vitro maturation of oocytes with special reference to goat: A review. Biotechnology. 7:599-611.

Shirazi A, Sadeghi N. 2007. The effect of ovine oocyte diameter on nuclear maturation. Small Rumin Res. 69:103-107.

Shirazi A, Shams-Esfandabadi, Hosseini SM, Karimi I. 2007. The presence of cumulus cells on nuclear maturation of sheep oocytes during in vitro maturation. Small Rumin Res. 68:291-295.

Suzuki K, Eriksson B, Shimizu H, Nagai T, RodriguesMartines H. 2000. Effect of hyaluronan on monospermic penetration of porcine oocytes fertilized in vitro. Int J Androl. 23:13-21.

Varishaga MD, Sumantri C, Murakami M, Fahrudin M, Suzuki T. 1998. Morphology classification of the ovaries in relation to the subsequent oocyte quality for IVF produced bovine embryos. Theriogenology 50:1015-1023.

Vassena R, Mapletoft RJ, Stefano A, Singh J, Adams GP. 2003. Morphology and developmental competence of bovine oocytes relative to follicular status. Theriogenology. 60:923-932. 